DOI: $\underline{\text { https://doi.org/10.24297/ijmit.v14i0.7896 }}$

\title{
The effect of E-Learning on Teachers' Motivation: A case study in Jeddah University
}

\author{
Tagreed Alsulimani ${ }^{1, a}$, Hadhami Kaabi ${ }^{1, b}$ \\ ${ }^{1}$ College of Business, University of Jeddah, Saudi Arabia \\ a tsalsilimani@uj.edu.sa \\ bhekaabi@uj.edu.sa
}

\begin{abstract}
E-learning is defined as a learning tool that is supported by information and communication technology.

In the last ten years, E-learning has become the key issue of universities all over the world and has a significance impact on current higher education. The issue of utilizing novel information and communication technologies for teaching and learning, is therfore crucial. Before implementing an E-learning framework in Jeddah university, a questionnaire is established to highlight the ability of teachers' to use this new way of education or not. The results show that the teachers have favorable attitude towards the use of E-learning and new technologies to enhance the education.
\end{abstract}

Indexing terms/Keywords: E-learning, Information technology, Higher education, Motivation, Jeddah University

Subject Classification: E-Learning; Information Technology

Type (Method/Approach): Survey/Interview

\section{Introduction}

E-learning is described as the use of electronic technologies in learning, teaching and research. It provides a set of different tools to enhance the learning. It also defined as any learning that involves using internet or intranet [1]. E- learning, a web based method, is revolutionizing the scene of academic education today. It has some benefits, the most important of which is its practicality, including easy accessibility from anywhere, its flexibility, as it adapts to the needs and pace of learning, its profitability, by reducing the costs [2]. One also notes that the courses adapt to the individual preferences and with varied learners (auditory, visual, handicapped ...), it also offers immediate results giving constructive feedback, it is also unlimited, allowing the infinite use of resources and E-learning content across borders and finally we note that courses can be updated at any time .

However, we note also some limitations of E-learning, among them the lonely side of learning, some learners feel the need for personal contact with teachers, others feel uncomfortable with discussion groups and their virtual classmates. There is also the impersonal side of learning, although in front of a computer screen which is not real and then it can be dangerous to spend time in front of a screen if you are not familiar with it and without taking precautions at prerequisite to protect vision or to avoid possible physical problems [2]. To this we can add the need for a certain degree of self-discipline, at the risk for some to lose motivation by not feeling sufficiently accompanied by encouragement and finally, this can lead to a lack of control over the courses as some would be satisfied to fly over subjects without paying too much attention [3].

Thus, an effective E-Learning course involves time, experience, commitment, good communication skills and a real passion for learning. To answer many questions in this area, our research study mainly based on a questionnaire will help us answer some questions to understand the global perception of the teachers of the 
university in relation to E-learning. The following table (table 1) shows some advantages and disadvantages of E-learning for teachers, students and university [4].

Table 1: Advantages \& Disadvantages of E-learning for Students, teacher and university

\begin{tabular}{|c|c|}
\hline \multicolumn{2}{|r|}{ Students } \\
\hline Advantages & Disadvantages \\
\hline Flexibility in learning & No direct contact with teachers \\
\hline Complete autonomy & $\begin{array}{l}\text { Frequency and distrust in the use of digital and } \\
\text { educational tools }\end{array}$ \\
\hline Follow-up and self-assessment & \\
\hline $\begin{array}{l}\text { Management and independence } \\
\text { at work }\end{array}$ & \\
\hline \multicolumn{2}{|r|}{ Teachers } \\
\hline Advantages & Disadvantages \\
\hline $\begin{array}{l}\text { Provide the basic conditions for } \\
\text { assessing the level of learners }\end{array}$ & Lack of direct contact \\
\hline $\begin{array}{l}\text { Personal training in the use of } \\
\text { digital tools }\end{array}$ & Multiple procedures to be taken \\
\hline Flexibility in tables & Communications are mostly written \\
\hline Assist learners directly & Difficulties to control bad activities like cheating \\
\hline \multicolumn{2}{|r|}{ University } \\
\hline Advantages & Disadvantages \\
\hline Detailed reports & Fear of some learners \\
\hline Flexibles tables & $\begin{array}{l}\text { Investment in the purchase of technological equipment } \\
\text { (computer) }\end{array}$ \\
\hline $\begin{array}{l}\text { Group training (reducing the } \\
\text { number of learners) }\end{array}$ & $\begin{array}{l}\text { Companies have little or no information on e-learning } \\
\text { tools }\end{array}$ \\
\hline Low educational costs & Absence of incentives for some learners \\
\hline $\begin{array}{l}\text { The possibility of unifying and } \\
\text { personalizing educational units }\end{array}$ & Decreasing of institutions' social role \\
\hline $\begin{array}{l}\text { Sustainability of teaching tools and } \\
\text { resources }\end{array}$ & \\
\hline
\end{tabular}


Several papers have dealt with the issue of E-learning. In what follows some relevant research works are briefly presented:

Arkorful and Obaido have shown the role of E-learning to develop th higher education and have also presented some advantages and disadvantages of E-learning [4]. Brown et al. [5] have proposed the effective use of virtual environements in the education and its impact on the students.

Wlodkowski [6] points out that "learners learn more using computer-based instruction in comparison to traditional classroom methods." This research study shows the importance of distance learning and the gained benefits. Elkhouly [7] shows that a non trained teachers to use E learning may lead to several difficulties.

Some new technological approaches are essential to maintain a good quality for courses [8]: E-learning as an example, to assist lecturers in higher educational institutions. in [9], some educational strategies are built to suit different learning styles of students. This way of proceeding may motivate the students to use E-learning and thereby building their confidence. [10] deals with assessment of the influence of adaptive e-learning as a part of learning analytics on learning effectiveness of primary school. The authors have presented a method to assist students to select th appropriate courses.

[11] Alhabeeb and Rowley present the critical success factor of E-learning for both students and academic staff. throw a comparative study, this research show how to reach a successful E-learning in universities.

For more details and a developed literature, paper [12] presents current state of quality models of E-learning systems and addresses different technical aspects of E-learning due to rapid changement in information and communication technologies.

In saudi Arabia, E-learning has been implemented in higher education to enhance the traditional way of education. The education is based on both face to face and distance education. Many saudian universities are now implementing E-learning systems since it is known as one of the important areas of Saudi's national information technology policy for the last ten years. Since Jeddah university is recently created, this study aims to preliminary investigate the teachers' motivation within the E-learning. The research question consists to know the ability of teachers to adopt E-learning in Jeddah university.

\section{Research Methodology}

\subsection{Research Design}

How far teachers are ready to use novel information technology tools for a developed higher education, Elearning as an example? This question is the aim of our research paper.

The used data, suitable for the research aim, depends on the results of feedback from a questionnaire given to teachers to evaluate their willingness to use E-learning. The questionnaire is distributed for teachers from the College of Business(COB) of Jeddah University, Saudia Arabia. COB can offers insights into the factors affecting online education.

\subsection{Research Subjects}

The subjects of the research are teachers from College of Business of Jeddah university, Saudi Arabia. 70 teachers have answered 26 questions of the questionnaire. The teachers taking part in the questionnaire are as follows (see Table 2)

Table 2. The number of teachers participating in the questionnaire 


\begin{tabular}{|l|l|l|l|l|l|}
\hline $\begin{array}{l}\text { Gender/Academic } \\
\text { Title }\end{array}$ & $\begin{array}{l}\text { Teaching } \\
\text { Assistant }\end{array}$ & lecturer & $\begin{array}{l}\text { Assistant } \\
\text { Professor }\end{array}$ & $\begin{array}{l}\text { Associate } \\
\text { Professor }\end{array}$ & Professor \\
\hline Male & 8 & 3 & 14 & 5 & 4 \\
\hline Female & 10 & 1 & 20 & 3 & 2 \\
\hline
\end{tabular}

\subsection{Data Collection}

The questionnaire designed for screened teachers from College of Business of Jeddah university includes:

a) Information of the subjects participating in the survey

b) The survey contains the following parts:

- Part 1: Groups of questions to study the ease of use of E-learning by the subjects.

- Part 2: Understanding about attitude, behaviors of the subjects when they use E-learning Attitude towards use.

- Part 3: Understanding about the expected benefits from E-learning.

- Part 4: Understanding about the behavioral intentions of using E-learning by teachers.

- Part 5: Groups of questions to test the teachers level of optimism towards the use of technologies.

- Part 6: Understanding about the ability of teachers to use advanced technologies.

- Part 7: To study the disturbance caused by technologies.

- Part 8: To study the degree of insecurity felt by teachers when using technologies

The teachers were asked to choose one option of (Strongly Agree $=5$ points, Agree $=4$ points, Undecided $=3$ points, Disagree $=2$ points, Strongly Disagree $=1$ points) for each question.

\section{Research Findings}

Teachers' attitudes towards using information technologies in higher education is reported through the results of the questionnaire.

The results of the main axes of the E-learning questionnaire are resumed in figure 1 . It can be seen from this figure that the attitude towards use and the behavioral intent of teachers according to the E-learning, have the highest percentages (about 26\%), in comparison with the rest of the questionnaire axes. However, the ease of use of information technologies tools remains low (about 9\%). Therefore, university must provide more workshops to encourage teachers and facilitate the use of technology.

Figure1: Result of the main axes of the E-learning questionnaire at College of Business 


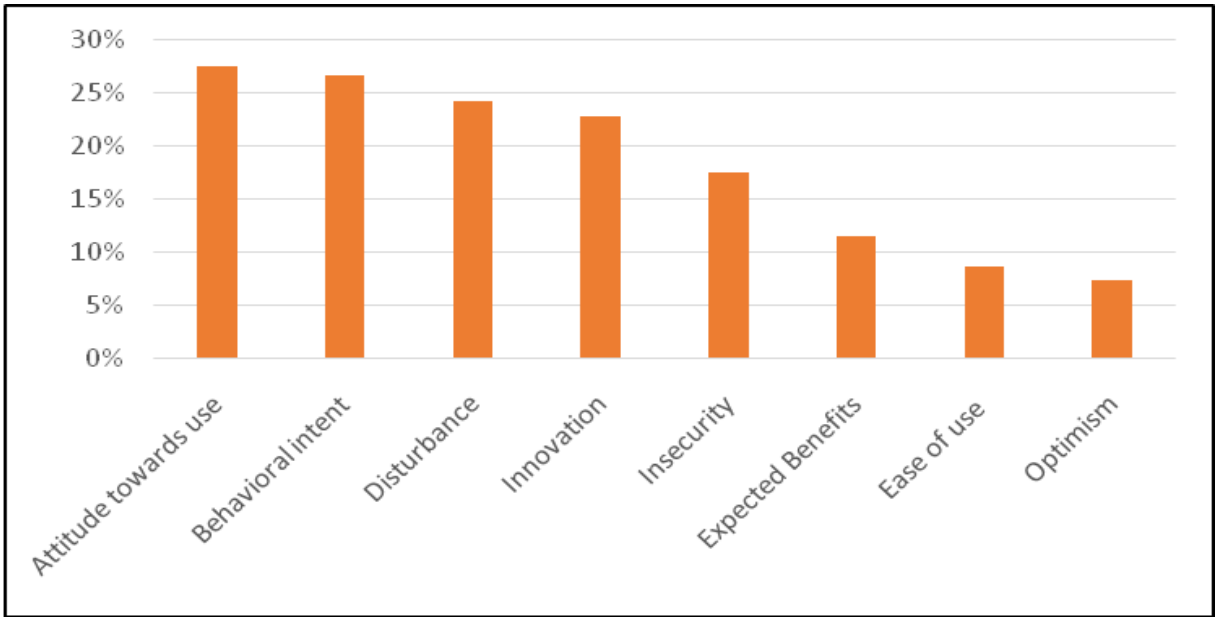

The principle axes are divided into two parts: Teachers' positive and negative opinions . It is clear that teachers present a high level of optimism ( $80 \%$ of positive opinions) against $6 \%$ of negative opinions.

$70 \%$ of teachers estimate that it is easy to use novel information technologies especially E-learning. However $9 \%$ considers that it is not easy to use E-learning.

Figure 2: Positive Opinions of the main axes of the E-learning questionnaire

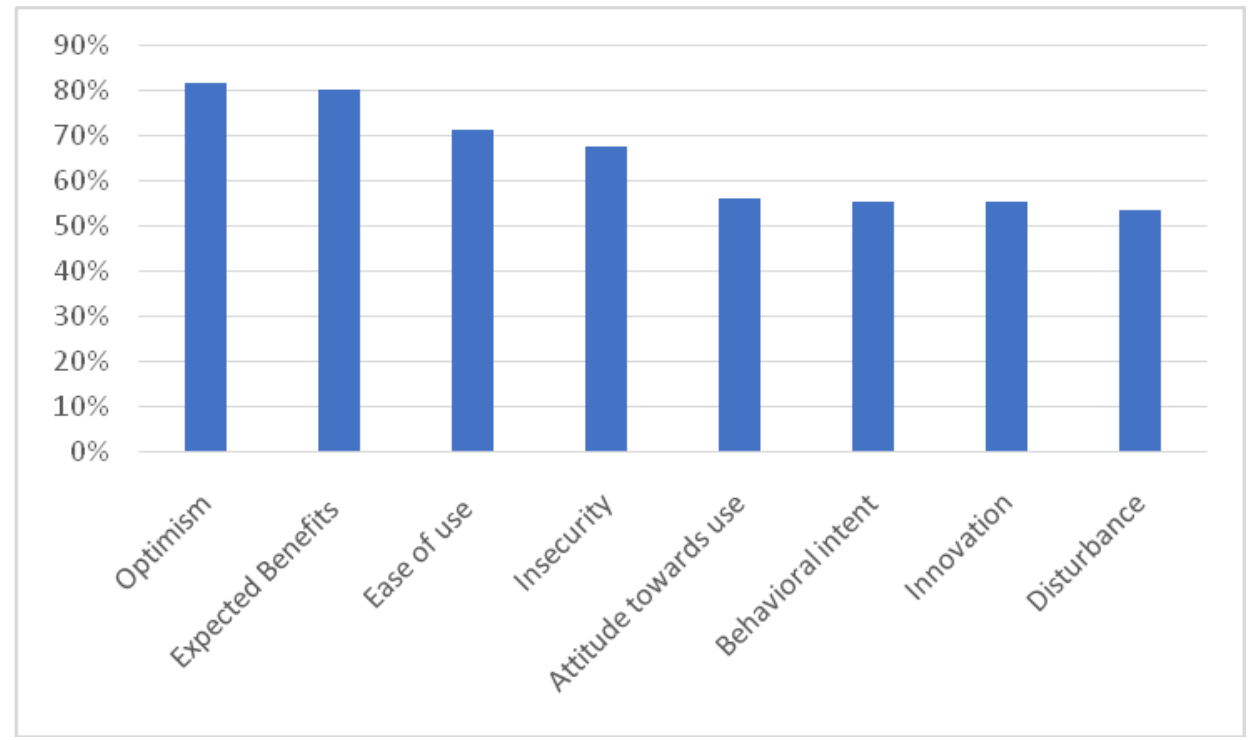

Figure 3: Negative Opinions of the main axes of the E-learning questionnaire 


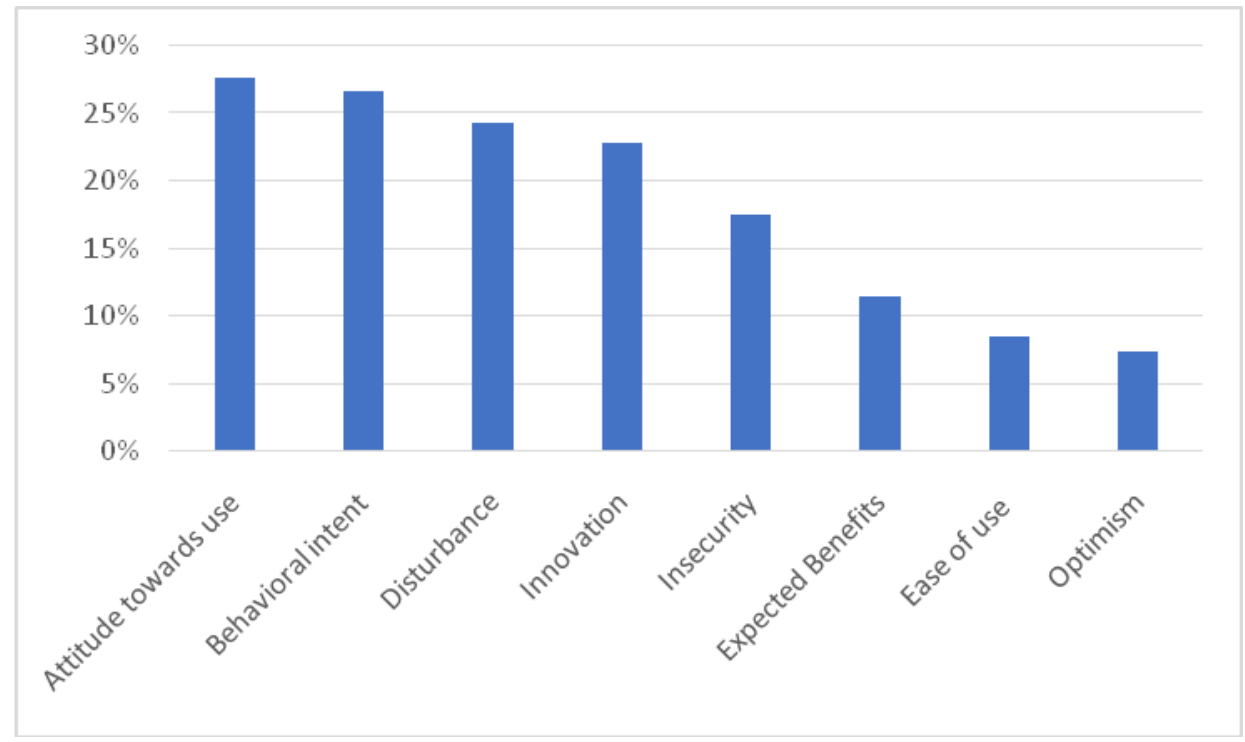

The results of some axes of the questionnaire will be depicted in details in what follows.

\subsection{Ease of Use of E-learning}

Figure 4: It is easy to train on E-learning

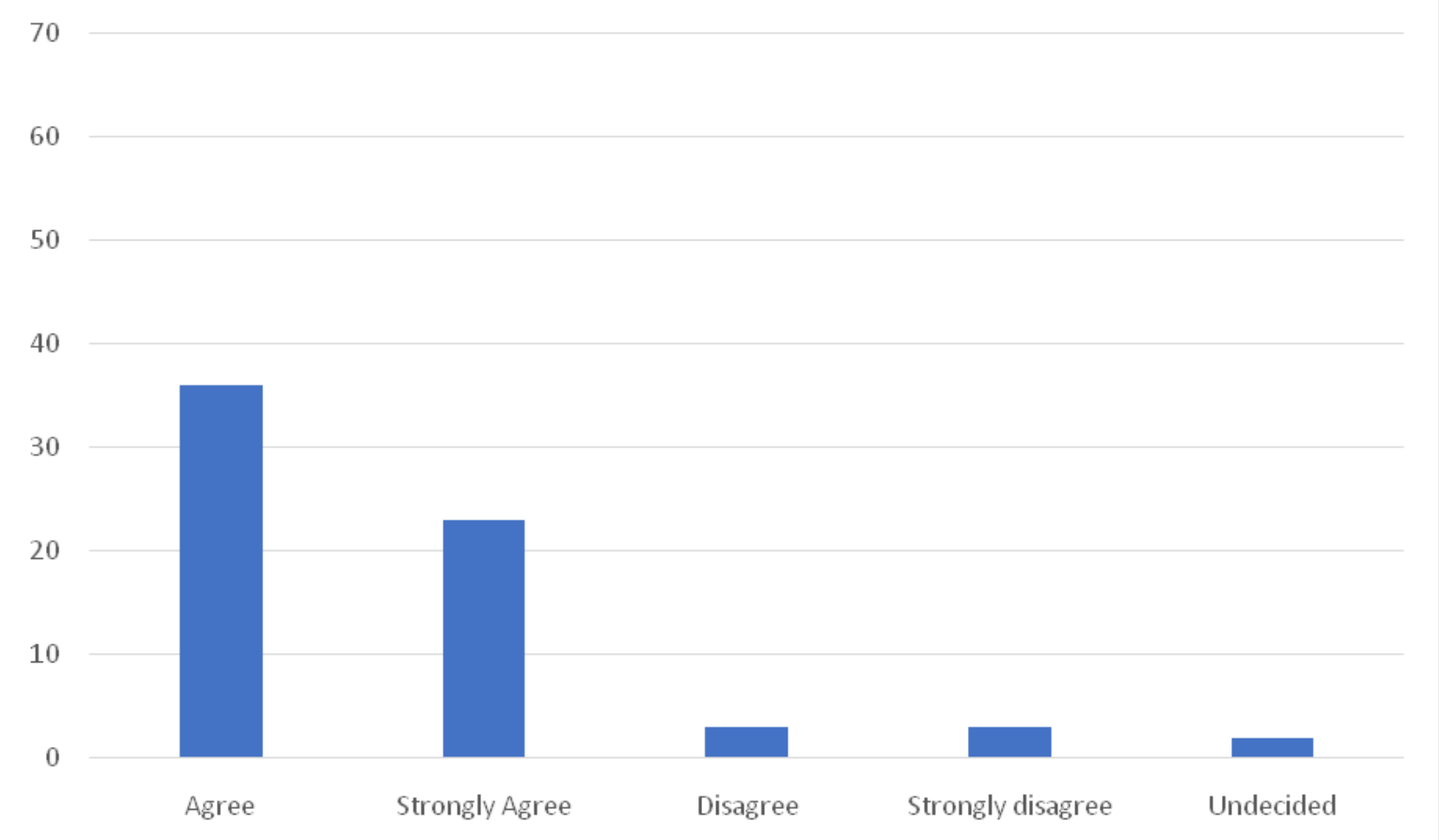

Figure 5: The use of E-learning is clear and understandable 


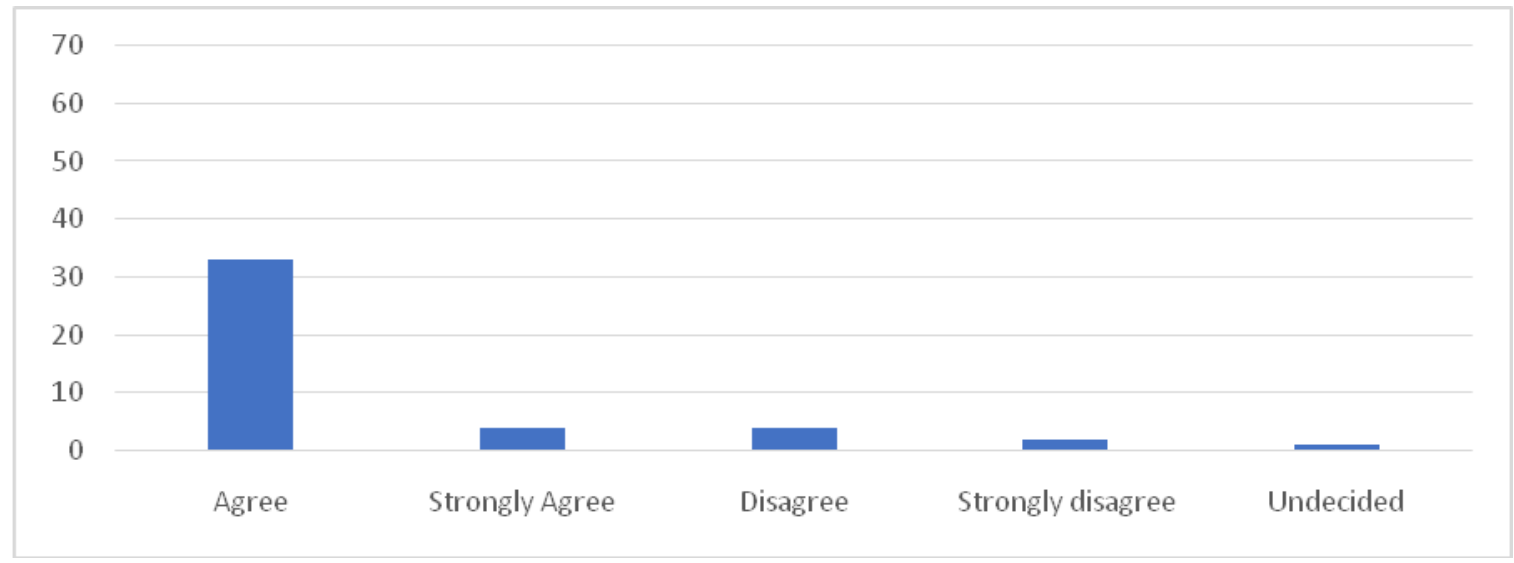

Figure 6: It is easy to use e-learning

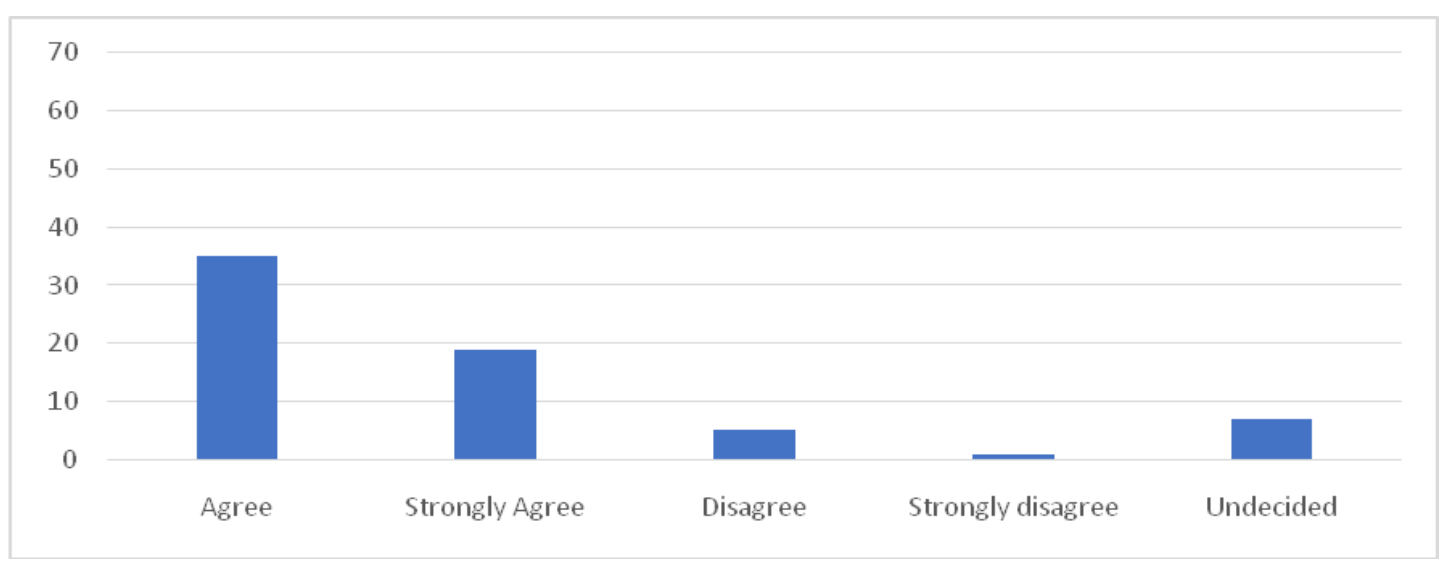

Through figure 4,5 and 6 , we can note that $71 \%$ agree that there is an ease of use of E-learning among them: 37 votes revealed that the use of e-learning is clear and understandable,59 of them have found that it was easy to practice e-learning, 54 votes found it easy to use e-learning.

\subsection{Attitude towards use}

Figure 7: E-learning makes teaching more interesting

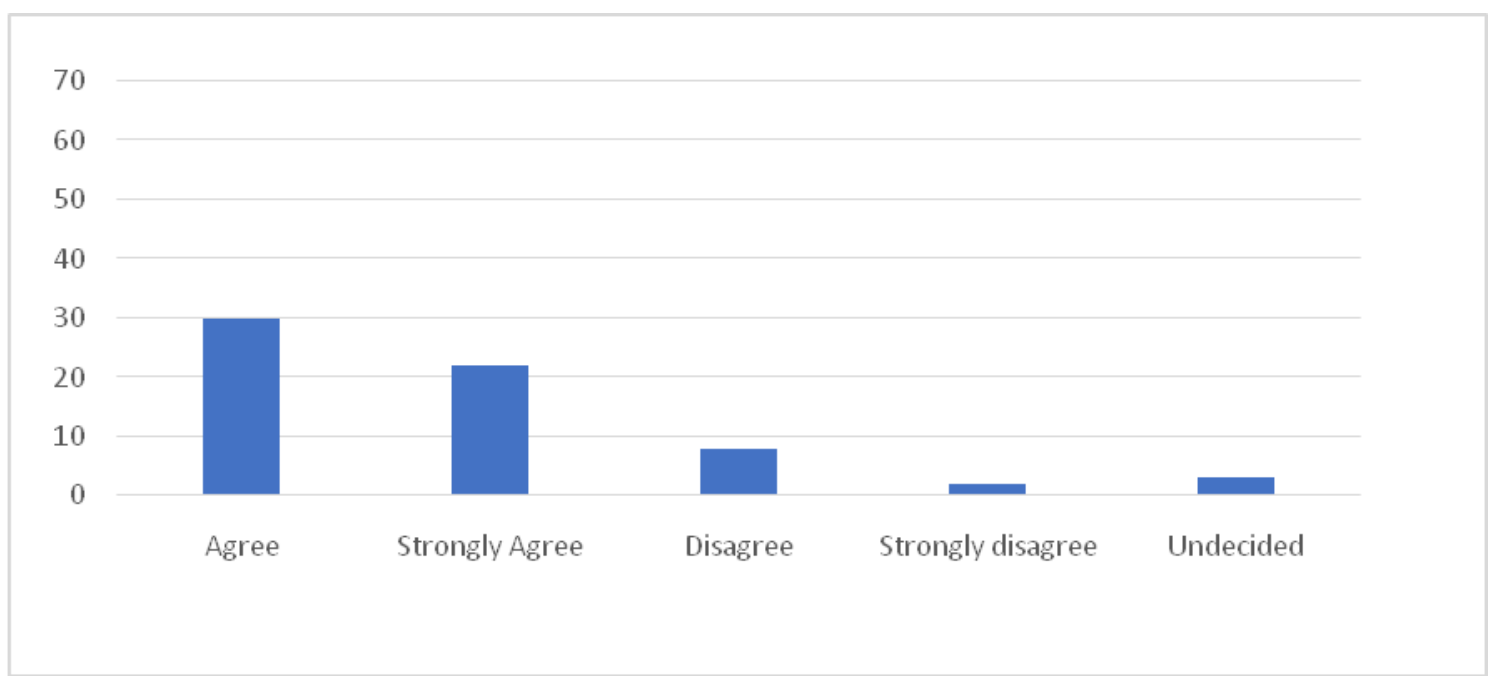

$54 \%$ agree that E-learning makes the teaching more interesting, while only $10 \%$ think the opposite 
Figure 8 : E-learning has no benefit

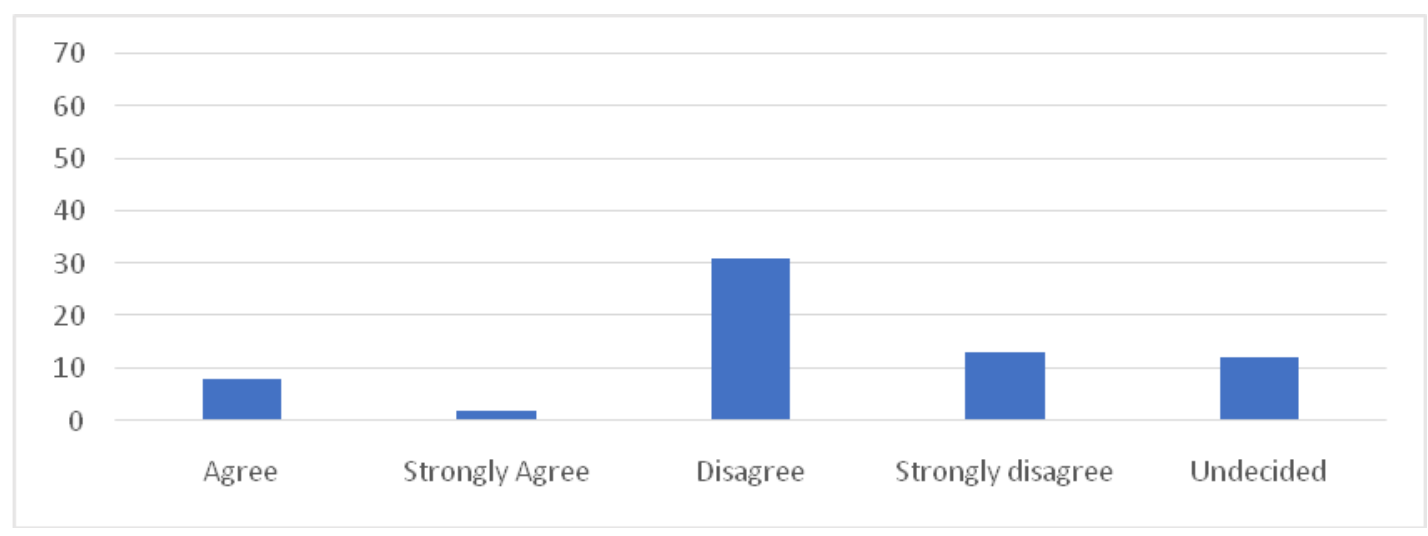

We notice that most of the teachers do not agree that E-learning has no benefit (see figure 8). 44 disagree with only 10 agreeing and 12 with no opinion on the issue. This proves that despite their reluctance, they remain favorable to this type of learning.

Figure 9: E-learning improves the quality of education

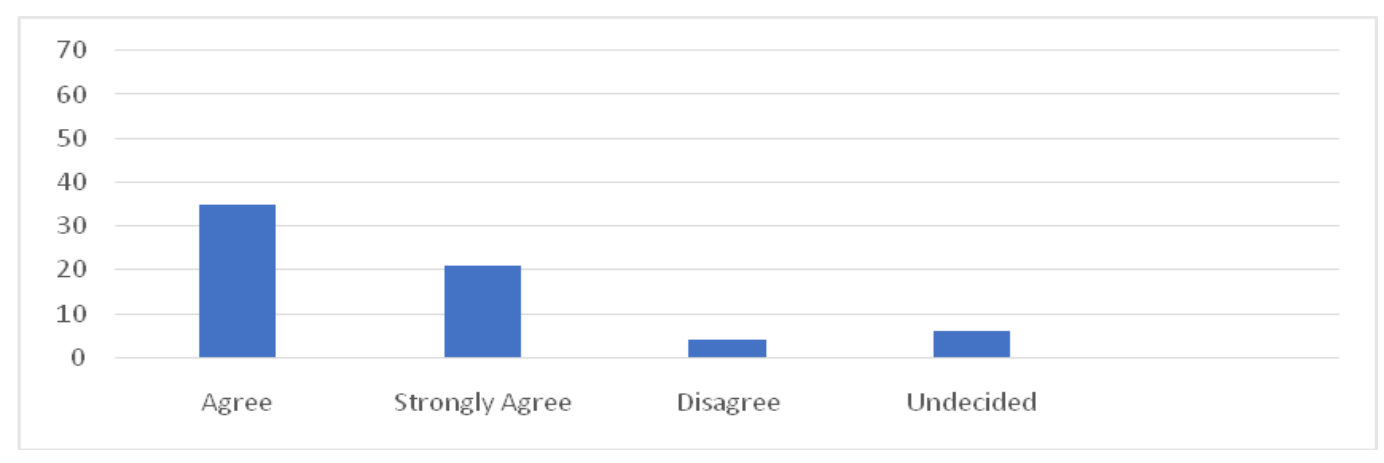

In the same vein as before, we find that 56 of them agree that E-learning improves the quality of teaching (see figure 9). It is also a positive opinion that shows their interest in this new method of learning.

\subsection{Expected Benefits}

Figure 10: E-learning facilitates students' access to knowledge

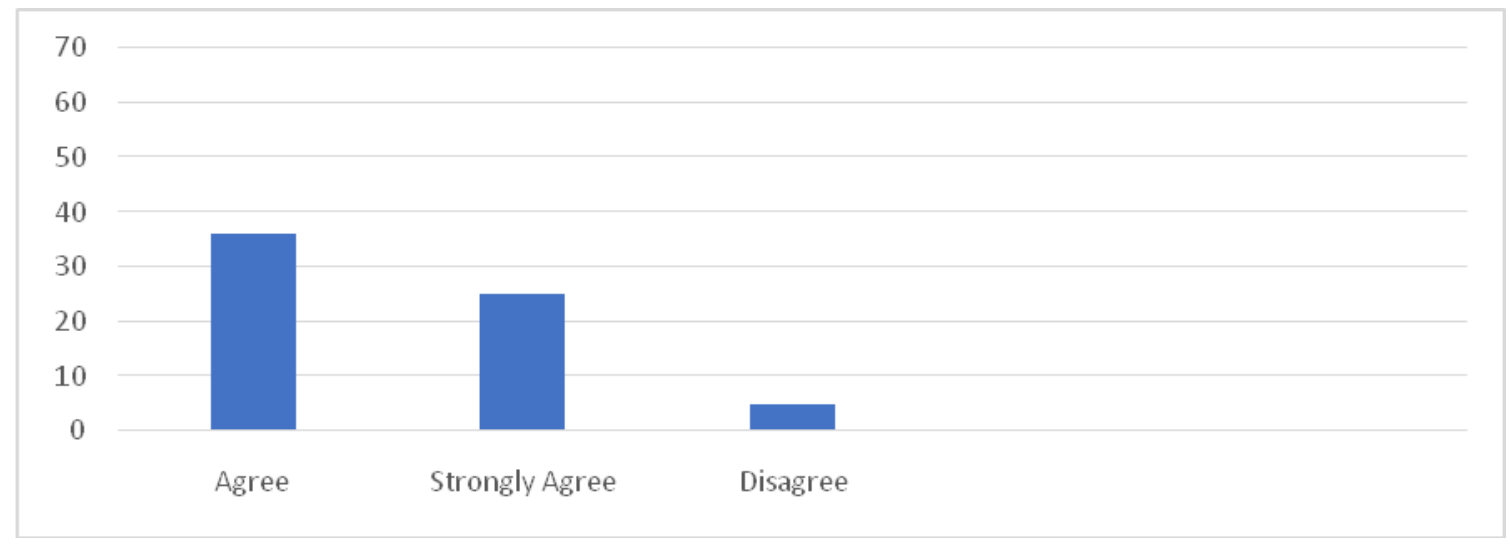

Figure 11: E-learning develops the student's learning potential 


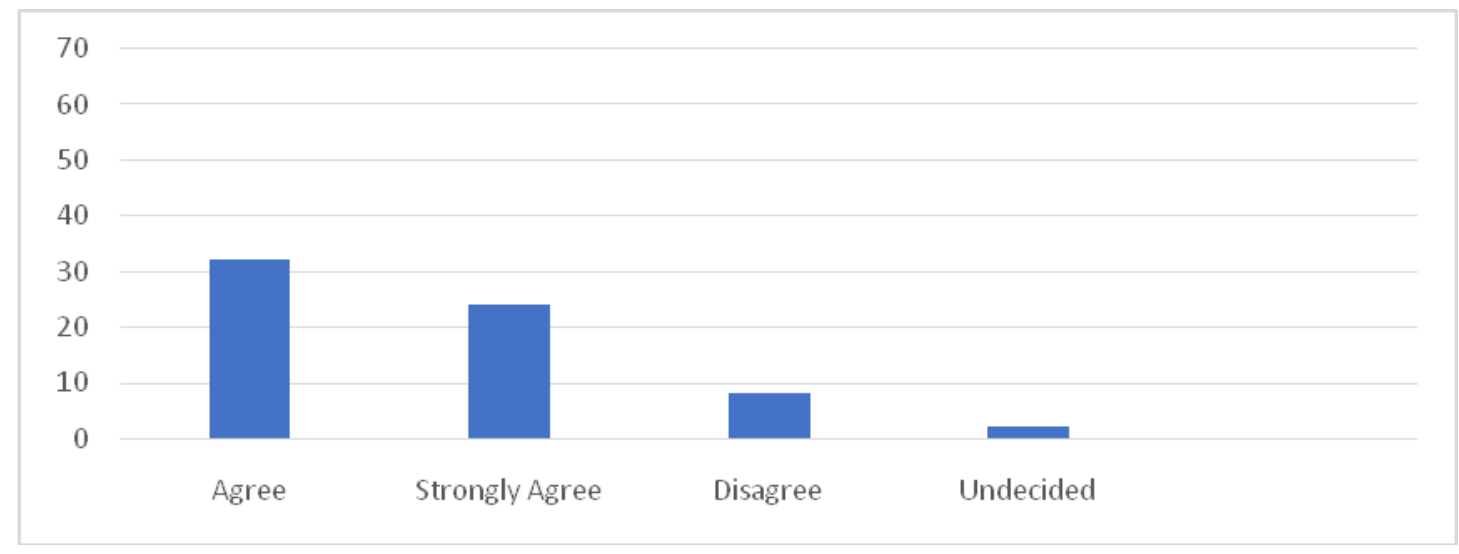

Figure 12: E-learning develops the student's learning potential

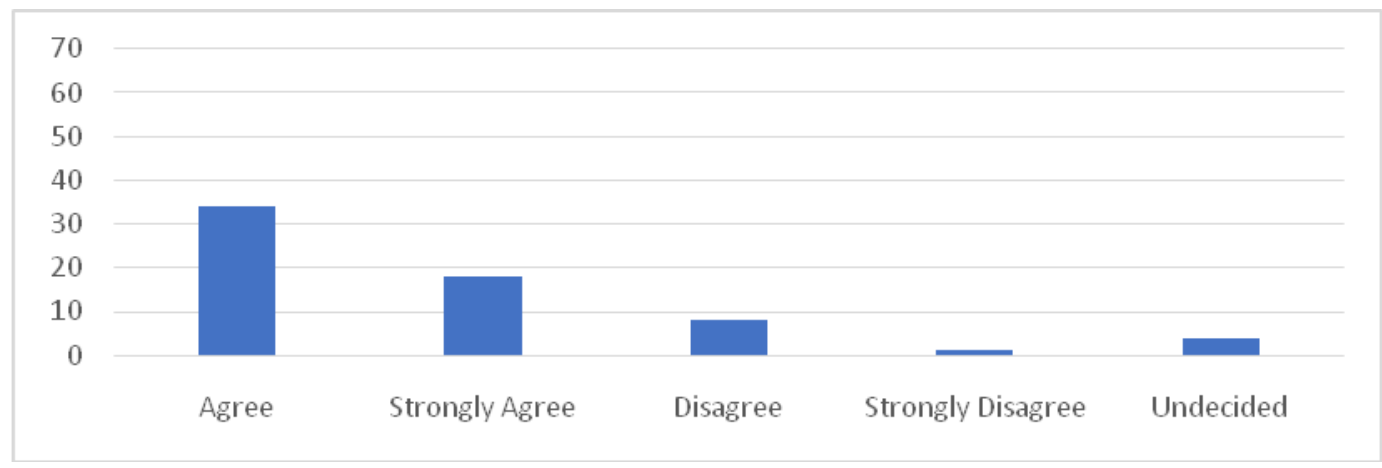

Figures 9,10 and 11 show that $80 \%$ find that there is an interest in online learning, compared to $11 \% .169$ votes out of 210 found that this way of learning is easy, that increases the knowledge and strengthens the students' abilities.

\subsection{Behavioral intent}

Figure 13: It would be better to limit the university to traditional education only

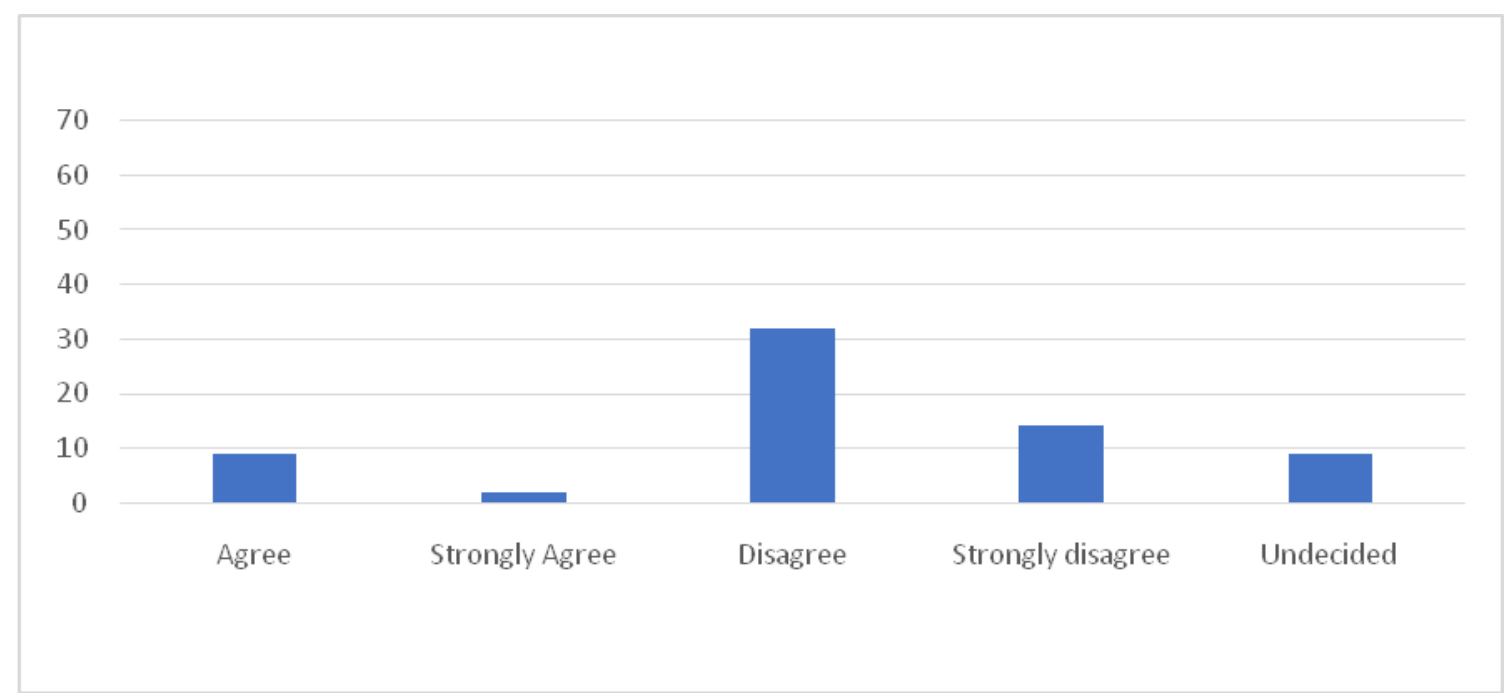


In relation with traditional education, 46 of teachers do not agree to rely solely on traditional education, against 11 only agreed and 9 without opinion. Despite the commitment to traditional teaching, we note that an absolute majority wants to change to more technological methods.

Figure 14: Intention to participate in the future in an advanced training course on E-learning

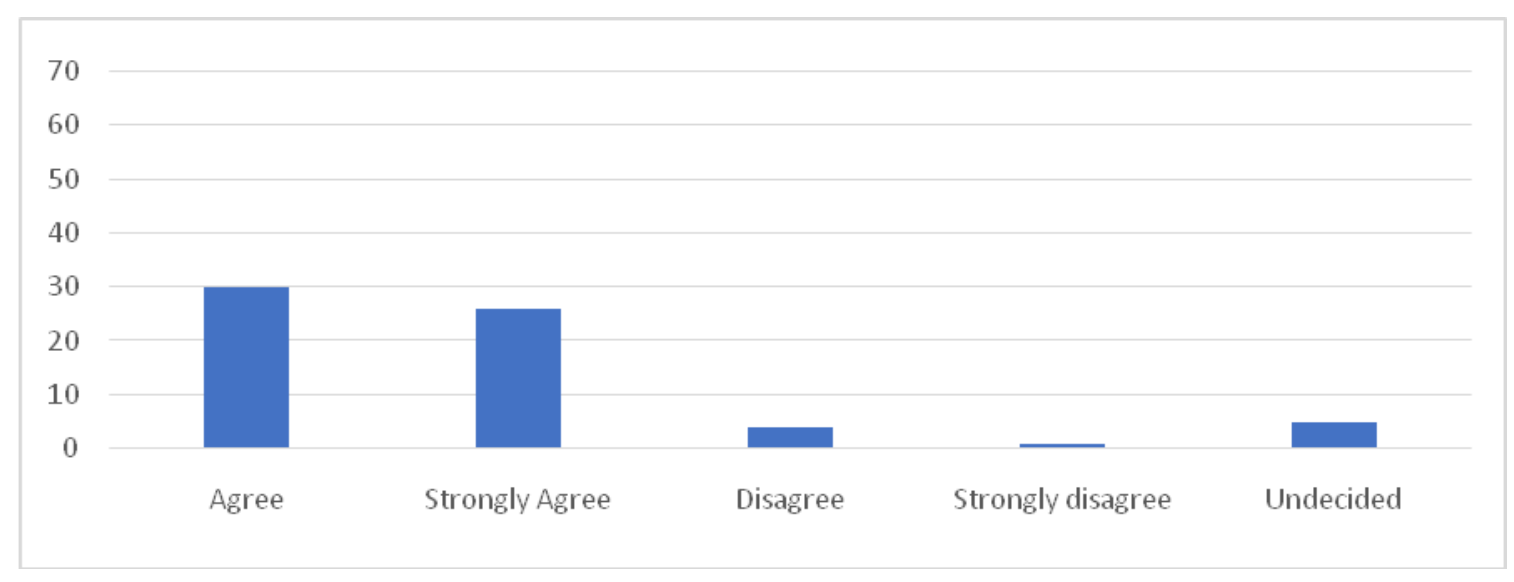

Figure 15: Intention to upload the course electronically

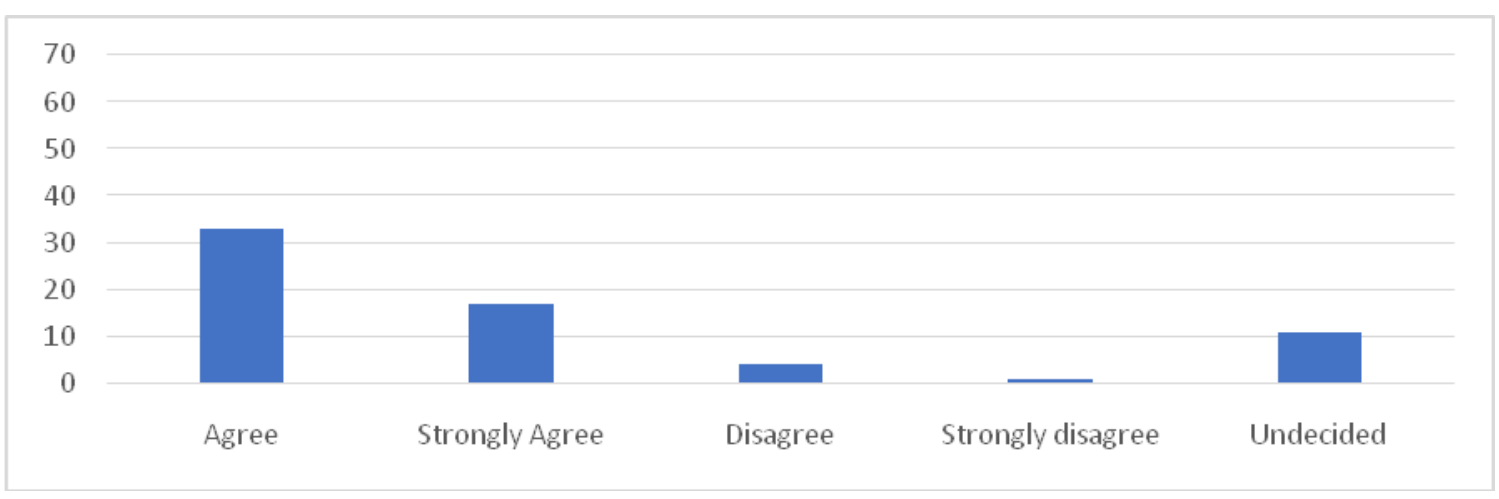

56 teachers plan to participate in an advanced training course on E-learning (see figure 14). And 50 of them will also download the course electronically (see figure 15).

\section{Discussions}

We notice that most participants (teachers) have a positive opinion on online learning. Some of them expressed reservations and others their lack of confidence in new technologies. They also pointed out, the importance of dealing directly with people, as 61 out of 70 participants who would like face-to-face education and only 5 would prefer indirect education. Which shows that despite their admiration for modern technology, they find that dealing directly with people is very important in terms of relationships.

In spite of the high rate of optimism in terms of online learning, about $82 \%$, it is difficult to convince some of teachers of the benefits of this type of education.

We also find a very interesting percentage that confirms the optimistic trend of this method, since $71 \%$ of respondents found that it was easy to use as well as understanding the tools of E-learning.

On the other hand, we notice a feeling of discomfort with new technologies. This is quite understandable as there is a certain mistrust of machines, especially when it comes to using online payments, for example, despite the guarantee and security presented. 
This would prove that even though accessibility is easy, it does not increase the trust factor among users of electronic machines.

This questionnaire shows first and foremost, that everything depends on how one puts oneself in front of the new technology, opinions can vary. There are those who feel comfortable with the new technology and those who are more confident while keeping some reserve on the total or absolute effectiveness of E-learning. On the other hand there are others, less comfortable, in front of the screens, find that they must be careful in front of their machines connected to an unknown space. This is why several aspects must be considered, including the cultural aspect that could be added to this questionnaire. In addition one should also consider the behavioral aspect. Properly, the result could vary from one personality to another. In fact, a person who is naturally autonomous and confident, or very comfortable with new technologies, would accept this learning transition more easily than a person who lacks confidence, who doubts and if in addition is inexperienced in new technologies.

\section{Conclusion}

In this paper, we can see how E-learning, which is developing over time, has gained attention

in Jeddah university. The results have shown the ability of teachers to adopt the new way of distance teaching. Benefits and usefulness of E-learning are also reported. To reach a developed higher education, teachers are ready to use novel information technology tools. The global trend is towards the exploitation of this new way of teaching, which is increasingly applied in universities as well as in private centers. The questionnaire confirmed that opinions are mostly positive, it shows the interest of this technology for teachers and therefore for students also.

\section{References}

[1] K.H. Fee, Delivering E-Learning: A Complete Strategy for Design Application and Assessment, 2005, London and Philadelphea: Kogan Page.

[2] A. Edmundson, Globalized e-learning cultural challenges. (USA: Idea Group Inc), 2007.

[3] H. Li, J. Masters, "ELearning and knowledge management in the early years: Where are we and where should we go", Knowledge Management and eLearning: An International Journal, 2009, 1(4), 245-250.

[4] V. Arkorful, N. Abaidoo",The role of e-learning, the advantages and disadvantages of its adoption in Higher Education", International Journal of Education and Research, 2014, 2(12), 397-410

[5] D. Brown, J. Cromby, P. Standen, The effective use of virtual environments in the education and rehabilitation of students with intellectual disabilities, 2001, British Journal of Educational Technology, 32(3), 289-299.

[6] R.J. Wlodkowski, "Adults in Modern Society are on a Lifelong Educational Journey", 2005. Retrieved from

http://userpages.umbc.edu/ koconne1/605TheAdultLearner/elearning.htm

[7] M. Elkhouly, Cases on challenges facing e-learning and national development: Institutional Studies and Practices, elearning in EGYPT, Volume I, Editor: Ugur Demiray, Anadolu University, Eskisehir-Turkey, 2010.

[8] D. Holley, "Which room is the virtual seminar in please?", Education and Training, 2002, 44(3), 112-121. http://dx.doi.org/10.1108/00400910210424283 
[9] M. Nehme, "E-Learning and Students' Motivation", 2010, 20 Legal Education Review, 223-239, SSRNid2347142

[10] S. Hubalovski, M. Hubalovska, M. Musilek ,"Assessment of the influence of adaptive E-learning on learning effectiveness of primary school pupils", 2018, Computers in Human Behavior, In Press

[11] A. Alhabeeb, J. Rowle, " E-learning critical success factors: Comparing perspectives from academic staff and student", 2018, Computers \& Education, 127, 1-12

[12] V.Nikolic, J. Kaljevic, S. Jovic, D. Petkovic, M. Milovancevic, L. Dimitrov and P. Dachkinov, "Survey of quality models of e-learning systems", 2018, Physica A: Statistical Mechanics and its Applications, 511(1), 324-330

\section{Conflicts of Interest}

Authors of this research work do not have any conflict of interests 